\title{
Synapses and neural communication in neuropathological conditions
}

\author{
Alejandro Sánchez ${ }^{1 *}$, Dora L. Flores ${ }^{2,3}$, Eugenio Leyva ${ }^{1}$, and Carlos Castro ${ }^{2}$ \\ ${ }^{1}$ Faculty of Sciences; ${ }^{2}$ Faculty of Engineering, Architecture and Design. Universidad Autónoma de Baja California, Ensenada, Baja California, Mexico; \\ ${ }^{3}$ Department of Computer Science, Institute for Genomics and Bioinformatics and Center for Machine Learning and Intelligent Systems, University \\ of California, Irvine, California, USA
}

\begin{abstract}
The central nervous system (CNS) is an extraordinary and complex communication network that receives voluminous amounts of information simultaneously but is vulnerable to disease and injury. This research emphasizes on the importance of gap junctions in neuropathological conditions and neurodegenerative diseases. Namely, we explore the degree of participation of chemical and electrical synapses within an updated panorama of integrative molecular techniques used for their study. The number of electrical and chemical synapses that coexist in the human brain is unknown, yet they are present in almost all types of cells. Frequently, electrical and chemical synapses are found separately, yet sometimes mixed electrical-chemical synapses are found coupled or together. Unfortunately, synaptic dysfunction has adverse effects on organs and vital structures. In this review, we discuss the most common diseases derived from synaptic dysfunction, as well as their occurrence in Mexico. Similarly, we discuss current treatments for diseases involving human connexins. Studies on the CNS are important to understand how this system works and explain current action mechanisms used as treatments of neuropathologies.
\end{abstract}

Key words: Gap junctions. Nervous system. Neuropathologies.

\section{Sinapsis y comunicación neuronal en afecciones neuropatológicas}

\section{Resumen}

El sistema nervioso central (SNC) es una red de comunicación extraordinaria y compleja que recibe cantidades voluminosas de información simultáneamente, pero es vulnerable a enfermedades y lesiones. Esta investigación enfatiza la importancia de las uniones gap en condiciones neuropatológicas y enfermedades neurodegenerativas. A saber, exploramos el grado de participación de las sinapsis químicas y eléctricas dentro de un panorama actualizado de las técnicas moleculares integrativas utilizadas para su estudio. Se desconoce la cantidad de sinapsis eléctricas y químicas que coexisten en el cerebro humano, pero están presentes en casi todos los tipos de células. Con frecuencia, las sinapsis eléctricas y químicas se encuentran por separado, aunque a veces las sinapsis mixtas quimicoeléctricas se encuentran acopladas. Desafortunadamente, la disfunción sináptica tiene efectos adversos en los órganos y las estructuras vitales. En esta revisión discutimos las enfermedades más comunes derivadas de la disfunción sináptica, así como su ocurrencia en México. Del mismo modo, discutimos los tratamientos actuales para padecimientos neurológicos que involucran conexinas humanas. Los estudios

Correspondence:

*Alejandro Sánchez

E-mail: alejandroSG@uabc.edu.mx
Date of reception: $10-10-2019$

Date of acceptance: 31-01-2020

DOI: 10.24875/RMN.20000136
Available online: 18-05-2020

Rev Mex Neuroci. 2020;21(3):111-121

www.revmexneurociencia.com

1665-5044/ @ 2020. Academia Mexicana de Neurología A.C. Published by Permanyer. This is an open access article under the CC BY-NC-ND license (http://creativecommons.org/licenses/by-nc-nd/4.0/). 
sobre el SNC son importantes para comprender cómo funciona este sistema y explicar los mecanismos de acción actuales utilizados como tratamientos de neuropatologías.

Palabras clave: Uniones de hendidura. Sistema nervioso. Neuropatologías.

\section{Introduction}

The nervous system has five forms of communication: mechanical signaling, electrical signaling, short-range signaling, local signaling, and long-range signaling. Mechanical signaling involves adhesion and recognition, whereas electrical signaling is triggered by electrical synapses and gap junctions (GJs). Short-range signaling occurs thanks to chemical synapses and neurotransmitters, local signaling is triggered by hemichannels, and finally, long-range signaling involves neurohormones ${ }^{1,2}$.

In most animal cells, except isolated moving cells, intracellular channels are formed between the cytoplasm of adjacent cells. These channels ensure the exchange of ions, metabolites, and other messenger molecules, but they also mediate electrical coupling among connected cells $\mathbf{s}^{3,4}$. Similarly, specific intracellular channels are formed by multi-protein complexes, commonly known as GJs. Pathologies affecting GJs have adverse effects on vital organs, senses, and bones.

There are three families of unrelated proteins that are involved in electric synapses connexins, pannexins, and innexins (Fig. 1). The family of connexins comprises 20 members which are found only in chordates ${ }^{4}$, and some of them are expressed in the central nervous system $(\mathrm{CNS})^{5}$. On the other hand, pannexins are found in vertebrates, and innexins exist only in invertebrates.

A GJ channel is formed by two hemichannels, each from one of two neighboring cells, leaving a narrow 2-4 nm gap between them. Furthermore, some hemichannels only serve as a backdoor to important metabolites. Studies on the functional role of innexins in the nervous system of invertebrates generate results that are applicable to all animal species, particularly mammals. Therefore, in this review, we emphasize on the importance of invertebrate animal models, namely, Hirudo medicinalis, to study synaptic function and thus respond to complex questions in neuroscience. Similarly, we present a panorama of neurological disorders, in which synaptic dysfunction is a characteristic. Then, we compare this information to that reported in the literature about human connexins and current treatments of human neurological diseases.

\section{Hirudo development of the nervous system}

It is well-known that molecular interactions influence the development of virtually all types of cells, including nerve cells, during embryogenesis ${ }^{6,7}$. GJs are considered as important mediators of cell communication ${ }^{8}$. In fact, research has demonstrated that GJs play a key role in the development and preservation of nerve cells: GJ inhibition causes progenitor cells to cease proliferation, thus leading to cell differentiation, or even death ${ }^{9}$. Cells can affect one another and promote growth. Electrical synapses work both during the development of the nervous system and in adulthood. If an innexin is ectopically expressed, it creates new connections with adjacent neurons, thus forming new communication channels. However, if some innexins are blocked, new channels cannot be formed (Fig 2) ${ }^{9}$.

$H$. medicinalis is a well-known species of the genus Hirudo and the family of Hirudinidae; however, it is usually confused with another leech species, Hirudo verbana, mainly due to their physical resemblance and similar behavior (Fig 1). Due to the size of its neurons and the structure of its nervous system, $H$. medicinalis is a popular model in biology. It is used to study neuron-to-neuron communication, specifically GJs. The nervous system of $H$. medicinalis comprises 32 ganglia, which is considered as motor brains and contains 400 neurons of approximately $10-50 \mu$ in diameter. These characteristics make $H$. medicinalis neurons more accessible to neuroscience studies. Furthermore, ganglia six and seven contain the male and female sexual organs of this species, respectively ${ }^{9}$.

\section{Important cells of the nervous system}

GJs take part in electrical coupling and contribute to synapse regeneration after neuronal injury. There is an average of ten glial cells or neuroglia per neuron, which makes them the most abundant cell types in the CNS. Glial cells comprise macroglia (astrocytes and oligodendrocytes), microglia, and ependymal cells. Astrocytes are associated with the majority of neurological disorders and diseases, such as brain ischemia, Alzheimer's disease (AD), and epilepsy. Similarly, GJs can be related to the malignant degree and metastasis of 


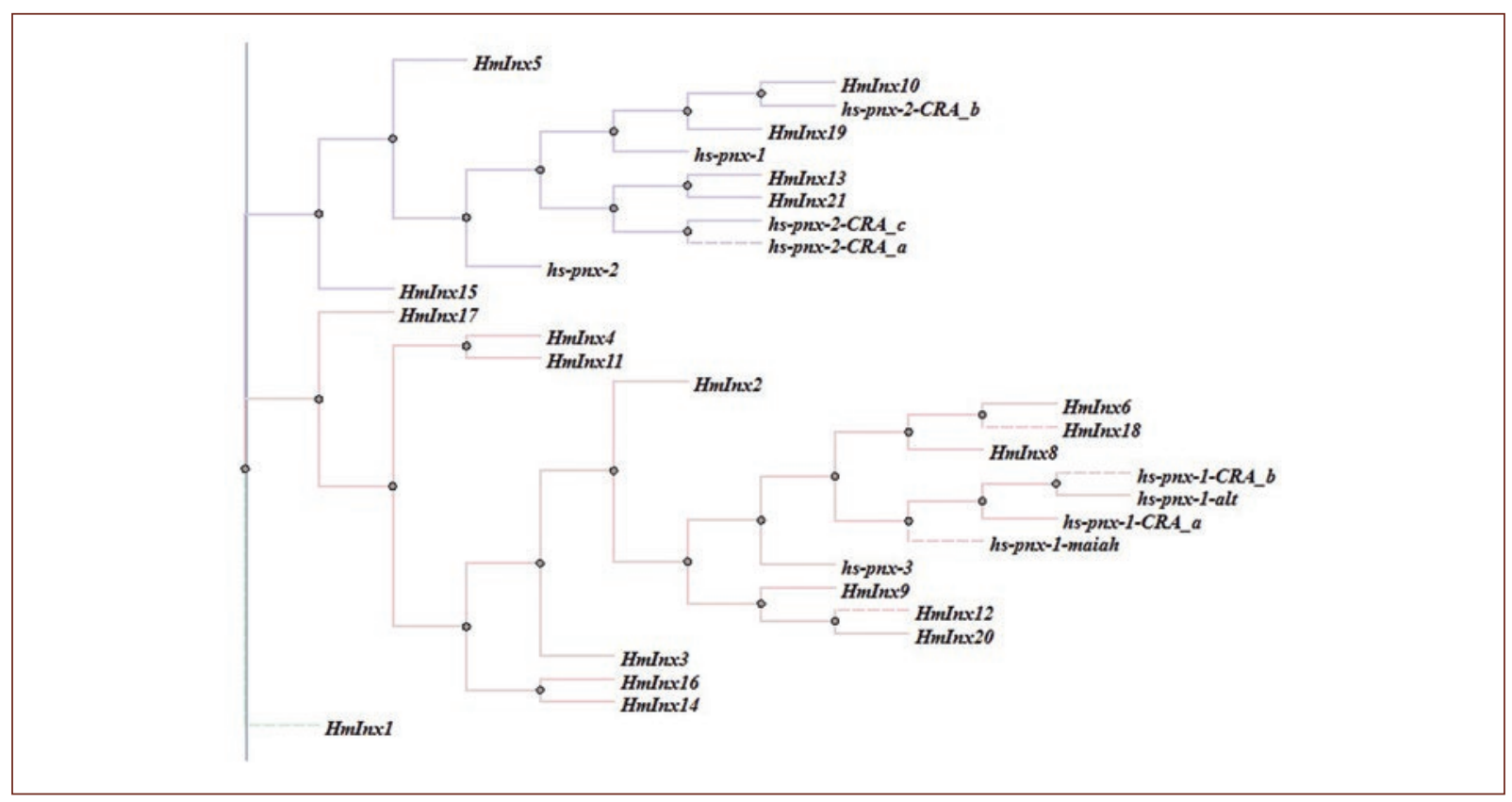

Figure 1. Cladogram showing innexins/pannexins of Hirudo medicinalis and Hirudo sapiens protein sequences.

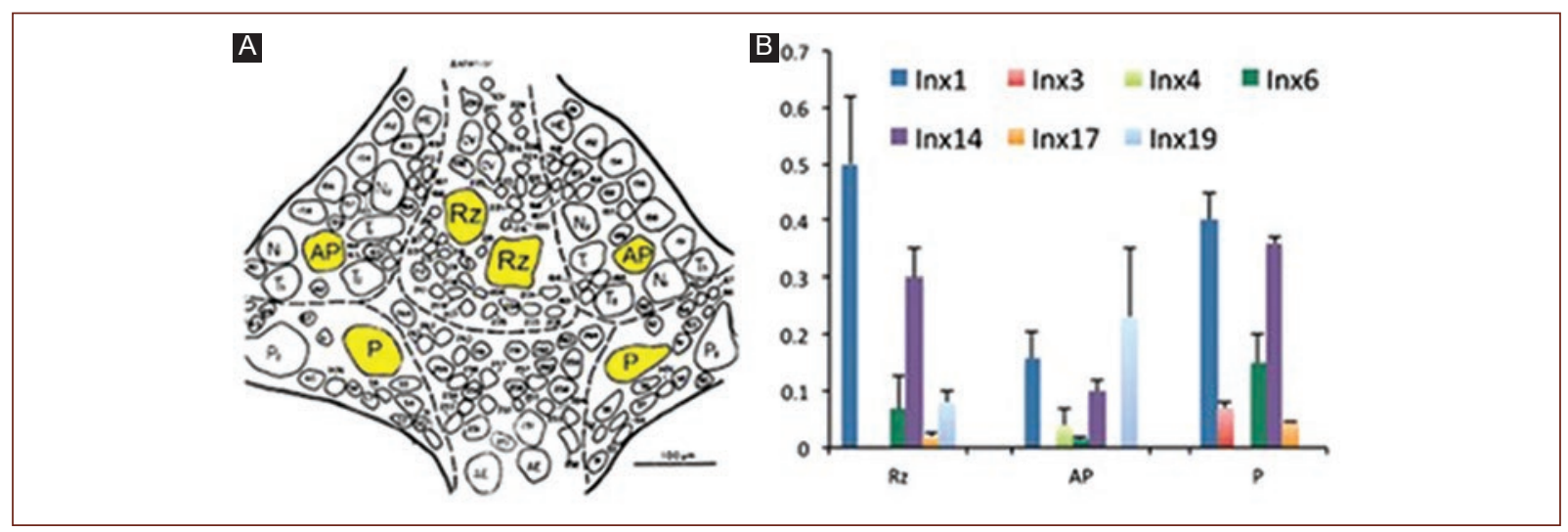

Figure 2. Characterization of Hirudo medicinalis adult neurons expressing different innexin transcriptions. A: ventral aspect of a single ganglion6; B: expressions of different innexins family members from quantitative polymerase chain reaction.

brain tumors, yet the functional role of most of these proteins is still unknown, particularly in the case of diseases of the nervous system ${ }^{9}$. Oligodendrocytes form the myelin that surrounds and protects axons, whereas microglia are the first and major form of active immune defense in the CNS. Astrocytes also exchange ions and metabolites, such as inositol 1,4,5-triphosphate, and adenosine triphosphate (ATP) through GJs. Similarly, oligodendrocytes maintain myelin using GJs. Furthermore, studies on brain ischemia and epilepsy using mice as biological models have managed to block GJs activity, thus addressing the possibility of neural protection to prevent brain ischemia or metabolic stress. Finally, it has also been demonstrated that macrophages can influence GJ expression in astrocytes, whereas activated microglia communicate using GJs ${ }^{9}$.

\section{Role of GJs in neuropathological conditions}

\section{Diseases introduction}

Knowing the functional role of GJs in conditions such as brain ischemia, neurodegenerative diseases, epilepsy, heart arrhythmia, cataracts, and tumors could allow experts to determine and understand the real molecular mechanism of GJ proteins network during disease 


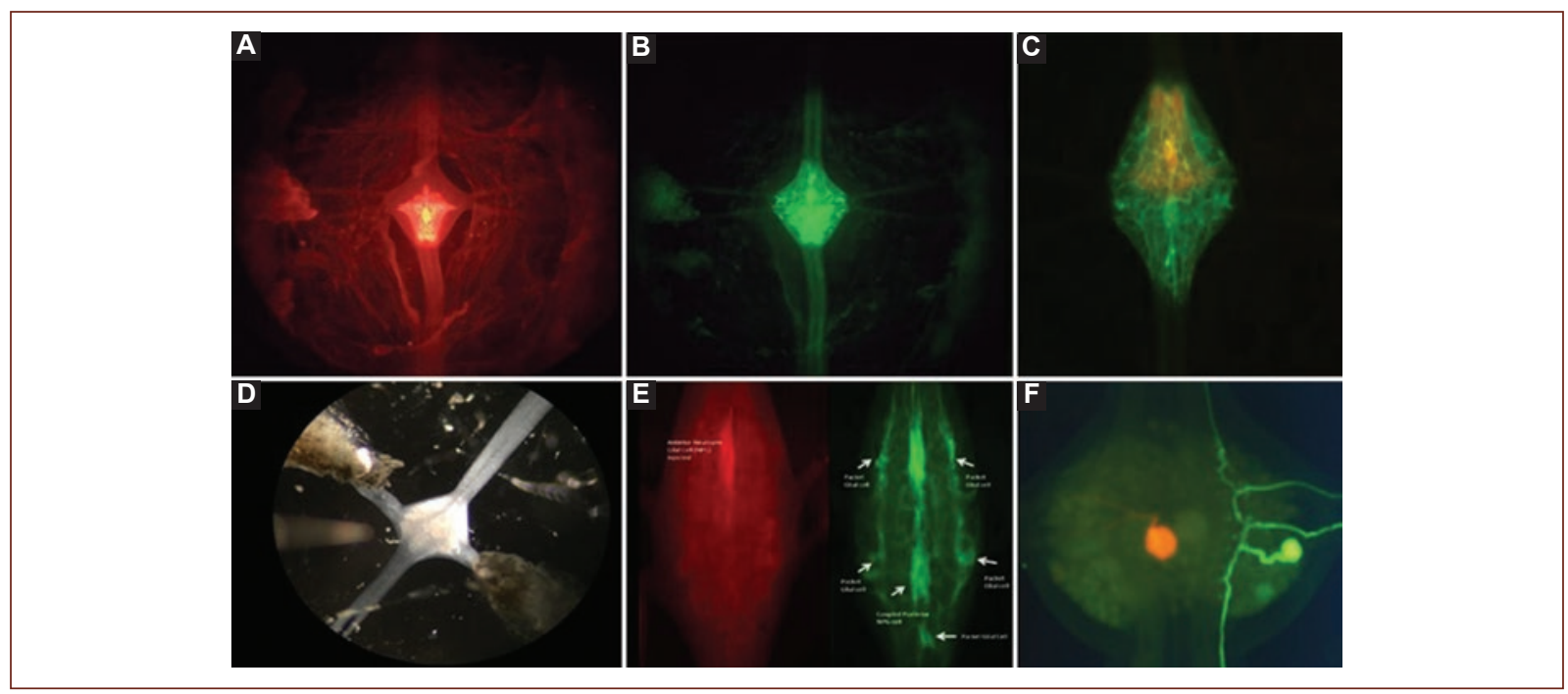

Figure 3. A: internal view of Hirudo medicinalis ganglion through epifluorescence using Lucifer yellow injection, neuropil is illuminated, B: internal view of $H$. medicinalis ganglion through epifluorescence using Neurobiotin, entire ganglion is illuminated, C: superposition of previous images, showing neuropil location in ganglion, D: ventral view of $H$. medicinalis ganglion - upper side corresponds to the organism's anterior connective tissue, E: control ganglion, red: TMR-dextran, green: Neurobiotin, F: visualization of the structure of a touch-sensitive neuron (T neuron) in ganglion using Neurobiotin.

processes, a practical separation of diseases based on the type of synapse involved, to simplify their study. Consequently, it could also help design treatments to successfully eliminate these conditions. Connexins and pannexins are key proteins to the bone and skeletal muscle development, maintenance, and regeneration. Research has found that connexin channels are present in the bone among osteoblasts, osteoclasts, and osteocytes. Similarly, connexins are important for bone growth and adaptation ${ }^{10}$.

The permeability of GJ channels is increased by multiple factors, including low pH levels, high cytosolic free calcium levels, and voltage gradient across the GJ. In vertebrate species, embryonic tissues are easily dissociated by treating them with low concentrations of a proteolytic enzyme, such as trypsin, along with a divalent-cation chelator, such as ethylenediaminetetraacetic acid, to disrupt the protein-protein interactions that hold the cells together.

The connection between cancer development and GJs was first reported by Loewenstein and Kanno when they studied liver cancer using electrophysiology techniques in $1966^{11}$. Twenty-four years later, it was already established that GJ mutations were linked to multiple human genetic diseases ${ }^{12}$. Nowadays, connexins are known to be related to the development of conditions such as hearing loss, skin disorders, congenital cataracts and other vision disorders, heart arrhythmia, demyelinating diseases, and oculodentodigital dysplasia ${ }^{13}$.
Although the exact percentage of electrical, chemical, or combined synapse participation is currently unknown, a simplification would help unravel the workings of opening neuronal communication channels during different conditions and would allow progress in these areas. At the molecular level, cellular communication plays a decisive role in the development or treatment of these diseases, and of course, the channels through which these signal molecules travel (Fig 3).

\section{Brain ischemia}

Cerebrovascular ischemia, or brain ischemia, occurs when there is insufficient blood flow to the brain. It leads to limited oxygen supply and can cause the death of brain cells. The side of the ischemic lesion has the same physiopathological mechanism and local consequences with different clinical manifestations, its severity, and its duration, yet sufferers can risk death. When a person presents symptoms of brain ischemia, they must receive emergency treatment. Even a temporary deficit in oxygen supply can impair the brain, when the brain is damaged as a result of ischemia, the consequences are severe (i.e., physical or mental disability or death). In fact, cerebrovascular diseases such as brain ischemia are a leading cause of death in the USA. Cerebral vascular disease is ranked as the second leading cause of death $(9.7 \%)$ in Mexico. 
The functional role of astrocytes and GJs in brain ischemia is still unclear, yet the two are known to fulfill a potentially neuroprotective function that involves ischemic tolerance and remodeling of neuronal networks by phagocytosis ${ }^{14}$. Experiments using cell culture techniques have demonstrated that blocking GJs in astrocytes make the cells more vulnerable to glutamate cytotoxicity ${ }^{15}$. Likewise, using hippocampal slice cultures, it was found that blocking GJs cause neuronal damage in ischemic conditions, such as oxygen and glucose deprivation ${ }^{16}$. GJs channels are known to remain open during these conditions ${ }^{17}$.

The most promising strategy for evaluating the functional role of connexins involves blocking them using interfering RNA, drugs such as carbenoxolone (CBX), and mimetic peptides, including Gap 19 and Gap $16^{17}$. Yet any state of overregulation can lead to microglial activation and neuroinflammation ${ }^{18}$. This strategy can help experts identify which connexins are implicated in apoptosis and inflammation. Consequently, it would be possible for scientists to develop new treatment options for brain ischemia. To date, Connexin 43 (Cx43) is the most promising connexin ${ }^{19}$. Cx43 expression is sensitive to neuronal injury and can be detected as early as $2 \mathrm{~h}$ post permanent middle cerebral artery occlusion (pM$\mathrm{CAO}$ ). These findings underscore $\mathrm{Cx} 43 \mathrm{GJ}$ as a potential early target for therapeutic intervention in ischemic stroke. Cx43 is potentially a useful early marker to delineate and investigate the ischemia progression ${ }^{19}$.

\section{Epilepsy}

Leading causes of epilepsy include infectious diseases and abnormal brain development. Epilepsy is a neurological disorder that develops as a result of abnormal brain function, neural communication anomalies, or imbalanced neurotransmitters - which are responsible for neurotransmission (i.e., communication between neurons). Hence, epilepsy occurs when neurons occasionally send abnormal signals in the brain ${ }^{20}$.

After a head injury, brain stroke, or any other accident, the brain might try to self-repair; however, this process can accidentally lead to abnormal brain connections, and thus epilepsy. During the epileptic crisis, many neurons send signals at the same time - as many as 500 times/s. This event causes changes in a person's behavior, movements, feelings, and levels of consciousness. Nowadays, epilepsy is referred to as a spectrum of disorders with a myriad of causes, severities, and effects. Some people may experience convulsions or lose consciousness, whereas others may simply stop what they are doing, have a short lapse of awareness, and stare into space for a moment without knowing what is happening around them ${ }^{20}$.

In general, a person is considered to have epilepsy after two unprovoked seizures; a "seizure" is a paroxysmal alteration of neurologic function caused by the excessive, hypersynchronous discharge of neurons in the brain, separated by at least $24 \mathrm{~h}$. Provoked seizures are caused by known precipitating factors, such as high fever, nervous system infections, acute traumatic brain injury, or fluctuations in blood sugar, or electrolyte levels. To date, nearly 2.3 million adults and 450,000 children and adolescents in the US suffer from epilepsy. In Mexico, there are about 2 million people with epilepsy, according to the Ministry of Health. Anyone can have epilepsy, men and women, regardless of their race, ethnicity, or age.

There are also severe cases of epilepsy, such as Dravet syndrome. This is a rare but lifelong dysfunction of the brain characterized by medically refractory seizures and causing serious learning disabilities. Current medications can control epilepsy in $60 \%$ of sufferers, whereas the remaining $40 \%$ experience what is commonly known as drug-resistant epilepsy. Nowadays, treatment options for epilepsy include about 20 different types of drugs, special diets, and surgical techniques, and medical specialty like neurosurgery. Common tests for epilepsy diagnosis include imaging and monitoring techniques (e.g., electroencephalography and magnetoencephalography), patient medical history, blood tests, behavioral tests, and neurological exams. $\mathrm{Cx} 43$ is related to cryptogenic epilepsy that is defined as a group of focal or generalized epilepsy, which are believed to be symptomatic of a histopathological or cellular occult alteration, but not of a genetic nature ${ }^{21}$.

Research has found that $\mathrm{Cx} 43$ in GJs ${ }^{21}$ and hemichannels ${ }^{22}$ adversely affects astrocyte function, thereby causing epileptic seizures, which in turn induce Cx43 expression ${ }^{23}$. On the other hand, changes in Connexin 36 (Cx36) expression cause cell death ${ }^{24}$ and neural communication anomalies, thus resulting in epilepsy $^{25}$. Furthermore, GJs in astrocytes play a crucial role in ionic regulation; particularly, they can change the concentration of potassium ions. Changes in the strength of GJ coupling can cause neuronal hyperexcitability, and consequently, spontaneous epileptic activity $^{26}$, which ultimately leads to astrocyte uncoupling. Finally, there is evidence that pannexin 1 (Panx1) contributes to the maintenance of epileptic seizures by releasing ATP. The absence of Panx1 in astrocytes 
potentiates seizure manifestation due to low levels of adenosine kinase, whereas the absence of Panx1 in neurons reduces seizure manifestation ${ }^{27}$.

\section{GJ blockers to treat epilepsy}

In a recent research Scemes et al. ${ }^{28}$, they studied 13 GJ blockers as treatment options for epilepsy: CBX, quinine, mefloquine, quinidine, anandamide, oleamide, heptanol, octanol, meclofenamic acid, niflumic acid, flufenamic acid, glycyrrhetinic acid, and retinoic acid. In the in vitro experiments, all these compounds demonstrated to have anticonvulsant effects in brain slices. The blockers modified the behavioral parameters related to seizures induced by 4-aminopyridine, pentylenetetrazol, pilocarpine, penicillin, and maximal electroshock. Similar research works suggest that GJ blockers are a future alternative for the treatment of epilepsy. Nevertheless, most of these compounds have been discontinued as treatments due to their side effects, thus implying that further research must be conducted to identify the action mechanisms for neurological disorders such as epilepsy (Table 1).

Multiple studies on connexins have been conducted with the aim of understanding and reporting the devastating effects of connexin dysfunctions (Table 2). Connexins are important, since they form synapses. Moreover, GJs are present in all biological cells, except spermatozoids, and some types of blood cells.

\section{Neurodegenerative diseases}

\section{$A D$}

$A D$ is the most common degenerative disease, in México, approximately 800,000 people have AD. Clinically, $A D$ is caused by cerebral atrophy of the frontal cortex, along with neurofibrillary tangle and large numbers of senile plaques. The ApoE4 allele is usually seen as a risk factor for $A D$, yet health experts also look for other indicators. That is, not everybody carrying the ApoE4 gene variant will go onto develop $A D$ as they grow old, although the probabilities are significantly higher. Moreover, some experts state that knowing that a person carries the ApoE4 allele does not benefit at all since none of the current treatment options cures the disease. ApoE gene polymorphic form ApoE4 ( $\varepsilon 4$ ) allele is the most commonly associated genetic risk factor linked with the late onset of the AD. In response to injury or neuroinflammation, Apo\&4 undergoes neuron-specific proteolysis. Even if it is not clear the relationship between this allele and $\mathrm{Cx} 43$, it will be interesting to focus on $\mathrm{Cx} 43$ function under this condition ${ }^{28}$. Thus far, the relationship between $A D$ and GJs remains unclear, yet glial cells are thought to contribute to the aggressive propagation of this disease by inhibiting cell communication and promoting neuroinflammatory responses ${ }^{29}$. Moreover, scientific evidence suggests a relationship between neurotoxicity of $A \beta 42$ deposits in $A D$ and upregulation of $\mathrm{Cx} 43$ as a result of released neurotoxic molecules that cause oxidative stress ${ }^{30}$.

That said, researchers have found that $\mathrm{C} \times 43$ prevents, to some extent, the brain from deteriorating; however, Cx43 overexpression identified in experiments on AD-like pathologies ${ }^{30}$ seems to severely affect intercellular communication, thus relating $\mathrm{Cx} 43$ overexpression with neuroinflammation.

Cx43 also seems to be involved in glutamate excitotoxicity induced by manganese exposure, thus promoting neurodegenerative diseases, such as $A D$ and Parkinson's disease (PD). Moreover, in the relationship between GJ activity in glial cells and glutamate excitotoxicity, the latter is linked to excessive NMDAR activity and neurodegeneration ${ }^{31}$. That said, two promising treatments of $A D$ include blocking specific GJs for $\mathrm{C} \times 43^{32}$ and the Metabolic Enhancement for Neurodegeneration (MEND) approach. MEND is a 36-point therapeutic personalized program including aspects such as medication, comprehensive dietary changes, vitamins, brain stimulation, and exercise, to name but a few. There is a revision that mentions the importance of $G J$ in $A D$, their positive and negative role in neurons and other cell types, expressing that there is a need for further investigation in a GJ oriented treatment for $A D^{33}$.

\section{PD}

PD is characterized by the loss of dopaminergic neurons in the part of the brain known as the substantia nigra (SN). There are no exact numbers of Parkinson's patients in Mexico. However, the National Institute of Neurology and Neurosurgery estimates a prevalence of 50 new cases per 100,000 inhabitants/year. Clinical symptoms include shaking, rigidity or tremor, and motor disorders such as bradykinesia which means slowness of movement, and it is one of the cardinal symptoms of Parkinson's (i.e., difficulty with walking). The 1-methyl-4-fenyl-1,2,3,6-tetrahydropyridine (MPTP) chemical model is used to represent the conditions of PD, and it causes permanent symptoms. MPTP is extensively modeled in mice and is characterized by overexpression of Cx43 in both the striatum and the astrocytic 
Table 1. GJ blockers and their side effects

\begin{tabular}{|l|l|l|c|}
\hline Blocker & Connexin & Side effects & Reference \\
\hline Carbenoxolone & Non-selective & Hydroelectrolytic disorders & 58 \\
\hline Quinine & C $\times 36, C \times 45, C \times 50$ & $\begin{array}{l}\text { Serious adverse events tinnitus, deafness, } \\
\text { dizziness, vomiting }\end{array}$ & 59 \\
\hline Mefloquine & $\mathrm{C} \times 36, \mathrm{C} \times 43, \mathrm{C} \times 50$ & Neurotoxic side effects following large doses & 12 \\
\hline Anandamide & $\mathrm{C} \times 32, \mathrm{C} \times 43$ & $\begin{array}{l}\text { Impact on calcium channels } \\
\text { Toxicity following large doses }\end{array}$ & 60 \\
\hline Heptanol & $\mathrm{C} \times 32, \mathrm{C} \times 43, \mathrm{C} \times 45$ & Unstated & 61 \\
\hline Octanol & $\mathrm{C} \times 43, \mathrm{C} \times 46, \mathrm{C} \times 50$ & Unstated & 61 \\
\hline Meclofenamic acid & $\mathrm{C} \times 36, \mathrm{C} \times 43, \mathrm{C} \times 50$ & None & 61 \\
\hline Niflumic acid & $\mathrm{C} \times 43, \mathrm{C} \times 45, \mathrm{C} \times 50$ & None & 61 \\
\hline Flufenamic acid & $\mathrm{C} \times 26, \mathrm{C} \times 32, \mathrm{C} \times 40, \mathrm{C} \times 43, \mathrm{C} \times 46, \mathrm{C} \times 50$ & None & 61 \\
\hline Glycyrrhetinic acid & Non-selective & None & 10 \\
\hline Retinoic acid & $\mathrm{C} \times 38$ & None & Reduce connexin function, temporarily \\
\hline Mimetic peptides & Specific & Unknown \\
\hline siRNA & Specific & & \\
\hline
\end{tabular}

hemichannels in the SN, thus contributing to the death of dopaminergic neurons ${ }^{34}$. In addition, MPTP animal models have shown accelerated neuron loss in the absence of $\mathrm{C} \times 30$ as a result of a disruption in astrocyte energy metabolism ${ }^{35}$.

A breakthrough in research on PD is the study of the inferior olivary nucleus (ION), which is a complex structure forming a bulge in the ventral surface of the medulla oblongata. The ION receives a wide range of sensory and motor afferents, and it is the source of the climbing fibers ascending to the cerebellum. Similarly, the ION is thought to play a key role in the generation of tremor in PD. Nowadays, olivary neurons are coupled by means of GJs, yet further research is necessary to determine their functional role. In other publications they mention the importance of focusing attention on the GJs for PD, for example, they say that GJ blocker treatment combined with inhibition of $\mathrm{K}_{+}$ channels might be a good approach to correct motor dysfunction in PD patients ${ }^{36}$ and that the use of GJ blockers in $\mathrm{PD}$ appears to be a promising treatment, it has been reported to improve motor function in hemiparkinsonian rats since GJ activity elicits beta oscillations in the basal ganglia nuclei, leading to akinesia in $\mathrm{PD}^{37}$.

\section{Brain tumors (glioma)}

A glioma is only one type of CNS tumor that originates in the glial cells of the brain or the spine. Gliomas are the most common type of brain tumors - they are space-occupying lesions causing intracranial pressure, vascular occlusion, and cerebral edema. In Mexico, an average of 30,000 new cases of brain cancer is detected annually, according to data provided by the Mexican Council of Neurological Surgery. The literature reports that in cases of severe gliomas, $\mathrm{C} \times 43$ is present in low concentrations; however, it is also known that the structure of $\mathrm{Cx} 43$ itself encourages glioma proliferation ${ }^{38}$. In addition, Cx43 suppresses tumor growth, regardless of GJ channels. Namely, it is believed that $\mathrm{Cx} 43 \mathrm{C}$-terminus directly inhibits tumor metastasis, possibly due to the correlation between $\mathrm{Cx} 43$ expression and protein kinase B (Akt)/extracellular signal-regulated kinase ${ }^{39}$. In other words, Cx43 acts as an inhibitory regulator of the activation of growth factor receptors, usually related to treatments for glioblastomas (GBM).

The study of brain tumor cells entails a deep study of the cell cycle. For instance, preliminary data have shown that $\mathrm{Cx} 43$ helps regulate the cell cycle during the $\mathrm{S}$ phase by interacting with a protein kinase ${ }^{40}$. However, Cx43 is also known to promote chemoresistance during GBM treatment by reducing the apoptotic effect of 
Table 2. Tissues and pathologies associated with connexins

\begin{tabular}{|c|c|c|c|}
\hline Connexin (Hirudo sapiens) & Tissue or site of expression & Mutation-related pathologies & Reference \\
\hline C x 26 (GJB2) & $\begin{array}{l}\text { Ependymal cells, pinealocytes, breasts, } \\
\text { cochlea, placenta, hepatocytes, pancreas, } \\
\text { kidneys, intestine, and epidermis }\end{array}$ & $\begin{array}{l}\text { Sensorineural hearing loss, } \\
\text { palmoplantar hyperkeratosis }\end{array}$ & $22,62,63,64$ \\
\hline C $\times 29 / C \times 30.2-31.3^{*}$ (GJC3) & $\begin{array}{l}\text { Heart, skeletal muscle, liver, myelinating } \\
\text { Schwann cells, Bergmann glia, and } \\
\text { oligodendrocytes }\end{array}$ & $\begin{array}{l}\text { Hearing impairment with } \\
\text { pathological changes in cochlea }\end{array}$ & $4,62,63,64$ \\
\hline$C \times 30$ (GJB6) & $\begin{array}{l}\text { Epidermis, cochlea, astrocytes, and } \\
\text { hippocampal pyramidal neurons }\end{array}$ & $\begin{array}{l}\text { Nonsyndromic hearing loss, } \\
\text { hidrotic ectodermal dysplasia }\end{array}$ & $11,22,64,65$ \\
\hline C x 31.9 (GJD3) & $\begin{array}{l}\text { Smooth muscle cells expressed in the } \\
\text { heart }\end{array}$ & Arrhythmia & $25,31,58,67$ \\
\hline C x 30.3 (GJB4) & Epidermis and kidneys & $\begin{array}{l}\text { Erythrokeratodermia variabilis } \\
\text { (EKV) }\end{array}$ & $29,64,66$ \\
\hline C x 31 (GJB3) & $\begin{array}{l}\text { Cochlea, auditory nerves, placenta, and } \\
\text { epidermis }\end{array}$ & $\begin{array}{l}\text { Hearing impairment, } \\
\text { erythrokeratodermia variabilis } \\
\text { (EKV) }\end{array}$ & $4,22,31,36,58,63,64$ \\
\hline C x 31.1 (GJB5) & $\begin{array}{l}\text { Middle and outer layers of the corneal } \\
\text { epithelium and epidermis }\end{array}$ & $\begin{array}{l}\text { Expressed upregulation in } \\
\text { corneas affected with Stevens- } \\
\text { Johnson syndrome (SJS) }\end{array}$ & 63,68 \\
\hline C x 32 (GJB1) & $\begin{array}{l}\text { Highly expressed in liver, pancreas, and } \\
\text { kidneys. Expression in the nervous } \\
\text { system is reduced to oligodendrocytes. }\end{array}$ & $\begin{array}{l}\text { Hereditary peripheral neuropathy, } \\
\text { Charcot-Marie-Tooth disorder } \\
\text { (CMTX) }\end{array}$ & $4,5,31,58,64,65$ \\
\hline C x 36 (GJA9/GJD2) & Neurons, microglia, and pancreatic B-cells & $\begin{array}{l}\text { Involved in gliomas, } \\
\text { astrocytomas, and glioblastomas }\end{array}$ & $14,22,65,69$ \\
\hline C x 37 (GJA4) & $\begin{array}{l}\text { Endothelial cells, granulosa cells, lungs, } \\
\text { and epidermis }\end{array}$ & Atherosclerosis & $4,13,29,58,66$ \\
\hline C x 40.1 (GJD4) & $\begin{array}{l}\text { Pancreas, kidneys, skeletal muscle, liver, } \\
\text { placenta, myoblasts, and heart }\end{array}$ & Muscular dystrophy & $3,4,31,58$ \\
\hline C x 40 (GJA5) & $\begin{array}{l}\text { Cardiomyocytes, endothelial cells, and } \\
\text { lungs }\end{array}$ & Arrhythmia & $4,31,66$ \\
\hline C x 43 (GJA1) & $\begin{array}{l}\text { Ubiquitous, highly expressed in astrocytes, } \\
\text { retinal cells, and basal layers of the } \\
\text { corneal epithelium and anterior stroma }\end{array}$ & $\begin{array}{l}\text { Oculodentodigital dysplasia } \\
\text { (ODDD), syndactyly type III, vaso } \\
\text { atrial heterotaxy, astrocytomas }\end{array}$ & $6,40,57,58,64,68,70$ \\
\hline C x 45 (GJA7/GJC1) & $\begin{array}{l}\text { Endothelial cells, neurons, smooth muscle, } \\
\text { myoblasts, neurons of the cerebral cortex, } \\
\text { claustrum, and olfactory bulb glomeruli }\end{array}$ & Muscular dystrophy & $3,4,31,58$ \\
\hline C x 46 (GJA3) & $\begin{array}{l}\text { Highly expressed in heart, placenta, } \\
\text { testis, chondrocytes, and ocular lens }\end{array}$ & $\begin{array}{l}\text { Autosomal dominant zonular } \\
\text { pulverulent cataract-3 (CZP3) } \\
\text { upregulated in breast cancer } \\
\text { cells }\end{array}$ & $7,12,22,69$ \\
\hline C x 47 (GJA12/GJC2) & $\begin{array}{l}\text { Oligodendrocytes along the surface of } \\
\text { internodal myelin }\end{array}$ & $\begin{array}{l}\text { Linked to neuropathies such as } \\
\text { Pelizaeus-Merzbacher-like } \\
\text { disease } 1\end{array}$ & 22,69 \\
\hline C x 50 (GJA8) & Ocular lens & $\begin{array}{l}\text { Zonular pulverulent cataract-3 } \\
\text { (CZP3) }\end{array}$ & 21,22 \\
\hline
\end{tabular}

temozolomide ${ }^{41}$. From this perspective, researchers have been able to identify cancer cell lineages with these characteristics ${ }^{42}$. In fact, identifying cells with aberrant Cx43 expression allow experts to develop new treatment options for brain tumors and block GJs to prevent chemoresistance ${ }^{43}$.

New approaches have been developed to identify tumor genesis response mechanisms. For instance, 
laser scanning microscopy (confocal laser scanning microscopy) and simple molecule localization microscopy are employed for the spatial localization of Cx43 in tumor genesis and the formation of metastasis ${ }^{44}$. Moreover, the literature reports epigenetic approaches for $\mathrm{Cx} 26$, $\mathrm{Cx} 30$, and $\mathrm{C} \times 43^{45}$. In fact, cell homeostasis can help suppress gliomas, yet it is also theorized that tumor cells affect neighbor cells through GJs ${ }^{46,47}$, whereas increased GJ regulation decreases the proliferation of glioma cells ${ }^{48}$.

\section{Autism}

Autism spectrum disorder (ASD) is a developmental disorder whose causes are usually unknown. It is influenced by multiple factors across race, ethnicity, and socioeconomic status aspects. According to the literature, in the USA, over 100 million families are affected by ASD. In 2017, around $1 \%$ of all children in Mexico, about 400,000 have autism. Recent evidence suggests that alterations of gut microbial-associated epitopes, including GJ alpha 1, can adversely affect the function of $\mathrm{C} \times 43^{49}$. Such results associate gastrointestinal problems in ASD with GJs and neuronal loss. In addition, research has found an increase in astrocytic $\mathrm{Cx} 43$ expression in a part of the brain's frontal cortex (i.e. Brodmann area 9) of subjects with autism, thus suggesting abnormal glial-neuronal communication in brains of ASD sufferers. Finally, studies on brain connectivity relying on electrophysiological techniques have used $H$. medicinalis as a key model to reduce the expression of specific connexins. In humans, this could help find a way to reduce overconnectivity in the brains of subjects with autism ${ }^{50}$.

New studies have emerged to diagnose neuropathologies with different novel approaches. Histochemistry was used to proper identify neurons, neuritic processes and axons, myelin sheaths, neuroglial cells, and connective tissue in the nervous system ${ }^{50}$. New strategies have been developed to predict ASD. One approach can be using genetic information contained in the Autism Genetic Resource Exchange; this database was used to predict the diagnostic of ASD in combination with an instrument of behavioral evaluation ${ }^{51}$. The other approach is the use of neuroimaging information which can be useful in the evaluation of psychiatric disorders. For ASD computational techniques were used to process magnetic resonance images of subjects with ASD and control groups ${ }^{52,53}$. There is no relationship between neuroimaging and GJs. Neuroimaging can be used as alternative information to try to evaluate the condition of a patient. Magnetic resonance procedures can be helpful to see the brain activity of patients with ASD. Moreover, computational techniques can be useful to process that information.

Symptom onset, genetic, and neuropathological data were examined from patients with Lewy body proteins to determine the relationship between those proteins and $A D^{54}$. In addition, postmortem magnetic resonance was used to examine serial coronal sections, horizontal sections of brainstem, and cerebellum to find neuropathological lesions ${ }^{54,55}$.

\section{Discussion}

The study of both the nervous system and neuropathologies through integrative molecular neuroscience requires not only fully-equipped laboratories and key biological models - such as $H$. medicinalis - but also extensive training on techniques such as injection of individual neurons, nanoballistics, and confocal microscopy, not to mention neuroimmunology and advanced histological techniques (Fig. 3).

Data show that connexin mimetic peptides can be used as GJ function blockers ${ }^{56,57}$ to disrupt innexin functions and to analyze the specific function and action of each member of the innexin family in $\mathrm{H}$. medicinalis. In this sense, results from research on the nervous system of $H$. medicinalis can be extrapolated to understand the functional role of GJs in the nervous systems of other species, including vertebrates.

\section{Conclusion}

According to the World Health Organization (OMS), disability is a complex phenomenon that reflects a close and borderline relationship between the characteristics of the human being and the characteristics of the environment where he lives. It is a broad term that contains and encompasses deficiencies, limitations to perform certain activities, and restrictions on participation. According to the National Human Rights Commission $(\mathrm{CNDH})$ in Mexico, disabilities are divided into motor, sensory, cognitive-intellectual, and psychosocial disabilities. If we analyze these disabilities at the cellular-molecular level, we can see a clear lack of cellular communication or defective communication between the neurons of the central and/or peripheral nervous system, a disconnection between different regions of the body.

The CNS plays a central role in the control of our bodily functions, yet failures in this system can cause multiple 
diseases and disabilities. Any CNS problem diagnosis is devastating. Studying GJs is important when trying to understand neuron-to-neuron communication. In fact, knowing and understanding the functional role of GJs in certain neuropathologies could allow experts to develop new treatment options to tackle such pathologies from the root cause. In this sense, $H$. medicinalis is a wellknown model used in in vivo experiments on neurons, innexins, and neurotransmitters.

Our work demonstrates that cell communication through GJs and electrical/chemical synapses is closely related to neurological conditions. However, evidence suggests that turning off connexins causes collateral damage or side effects that do not benefit humans. Additional and deeper in vivo studies are needed for a medical breakthrough and to find treatment options to cure neurological diseases.

\section{Funding}

None.

\section{Conflicts of interest}

None.

\section{Ethical disclosures}

Protection of human and animal subjects. The authors declare that no experiments were performed on humans or animals for this study.

Confidentiality of data. The authors declare that they have followed the protocols of their work center on the publication of patient data.

Right to privacy and informed consent. The authors declare that no patient data appear in this article.

\section{References}

1. Bruzzone R, White TW, Paul DL. Connections with connexins: the molecular basis of direct intercellular signaling. Eur J Biochem. 1996; 238:1-27.

2. Chailakhyan LM. Ligand-receptor and junction-mediated cell-cell interactions: comparison of the two principles. Differentiation. 1990;45:1-6.

3. Chernet BT, Fields C, Levin M. Long-range gap junctional signaling controls oncogene-mediated tumorigenesis in Xenopus laevis embryos Front Physiol. 2014;5:519.

4. Slivko-Koltchik GA, Kuznetsov VP, Panchin YV. Are there gap junctions without connexins or pannexins? BMC Evol Biol. 2019;19:46.

5. Esseltine JL, Laird DW. Next-generation connexin and pannexin cell biology. Trends Cell Biol. 2016;26:944-55.

6. Pereda AE. Electrical synapses and their functional interactions with chemical synapses. Nat Rev Neurosci. 2014;15:250-63.

7. Baranes K, Hibsh D, Cohen S, Yamin T, Efroni S, Sharoni A, et al. Comparing transcriptome profiles of neurons interfacing adjacent cells and nanopatterned substrates reveals fundamental neuronal interactions. Nano Lett. 2019;19:1451-9.
8. Mathews J, Levin M. Gap junctional signaling in pattern regulation: physiological network connectivity instructs growth and form. Dev Neurobiol. 2017;77:643-73.

9. Swayne LA, Bennett SA. Connexins and pannexins in neuronal development and adult neurogenesis. BMC Cell Biol. 2016;17 Suppl 1:10.

10. Plotkin LI, Davis HM, Cisterna BA, Sáez JC. Connexins and pannexins in bone and skeletal muscle. Curr Osteoporos Rep. 2017;15:326-34.

11. Loewenstein WR, Kanno Y. Intercellular communication and the contro of tissue growth: lack of communication between cancer cells. Nature. 1966;209:1248-9.

12. Mesnil M, Aasen T, Boucher J, Chépied A, Cronier L, Defamie N, et al. An update on minding the gap in cancer. Biochim Biophys Acta Biomembr. 2018;1860:237-43.

13. Laird DW, Naus CC, Lampe PD. SnapShot: connexins and disease. Cell. 2017; 170:1260-0.

14. Koizumi S, Hirayama Y, Morizawa YM. New roles of reactive astrocytes in the brain; an organizer of cerebral ischemia. Neurochem Int. 2018:119:107-14.

15. Ozog MA, Bechberger JF, Naus CC. Ciliary neurotrophic factor (CNTF) in combination with its soluble receptor (CNTFRalpha) increases connexin43 expression and suppresses growth of C6 glioma cells. Cancer Res. 2002;62:3544-8.

16. Liu Z, Chopp M. Astrocytes, therapeutic targets for neuroprotection and neurorestoration in ischemic stroke. Prog Neurobiol. 2016;144:103-20.

17. Chen Y, Wang L, Zhang L, Chen B, Yang L, Li X, et al. Inhibition of connexin 43 hemichannels alleviates cerebral ischemia/reperfusion injury via the TLR4 signaling pathway. Front Cell Neurosci. 2018;12:372.

18. Yin X, Feng L, Ma D, Yin P, Wang X, Hou S, et al. Roles of astrocytic connexin-43, hemichannels, and gap junctions in oxygen-glucose deprivation/reperfusion injury induced neuroinflammation and the possible regulatory mechanisms of salvianolic acid B and carbenoxolone. J Neuroinflammation. 2018;15:97.

19. Freitas-Andrade $M$, She J, Bechberger J, Naus CC, Sin WC. Acute connexin43 temporal and spatial expression in response to ischemic stroke. J Cell Commun Signal. 2018;12:193-204.

20. National Institutes of Health. National Institute of Neurological Disorders and Stroke. Bethesda, MD: National Institutes of Health; 2019.

21. Shandra O, Winemiller AR, Heithoff BP, Munoz-Ballester C, George KK, Benko MJ, et al. Repetitive diffuse mild traumatic brain injury causes an atypical astrocyte response and spontaneous recurrent seizures. J Neurosci. 2019;39:1944-63.

22. Walrave L, Pierre A, Albertini G, Aourz N, De Bundel D, Van Eeckhaut A, et al. Inhibition of astroglial connexin43 hemichannels with TAT-Gap19 exerts anticonvulsant effects in rodents. Glia. 2018;66:1788-804.

23. Ran X, Xiang J, Song PP, Jiang L, Liu BK, Hu Y. Effects of gap junctions blockers on fast ripples and connexin in rat hippocampi after status epilepticus. Epilepsy Res. 2018;146:28-35.

24. Belousov AB, Nishimune H, Denisova JV, Fontes JD. A potential role for neuronal connexin 36 in the pathogenesis of amyotrophic lateral sclerosis. Neurosci Lett. 2018;666:1-4.

25. Wu XL, Ma DM, Zhang W, Zhou JS, Huo YW, Lu M, et al. Cx36 in the mouse hippocampus during and after pilocarpine-induced status epilepticus. Epilepsy Res. 2018;141:64-72.

26. Du M, Li J, Chen L, Yu Y, Wu Y. Astrocytic Kir4.1 channels and gap junctions account for spontaneous epileptic seizure. PLoS Comput Biol. 2018;14:e1005877.

27. Plata A, Lebedeva A, Denisov P, Nosova O, Postnikova TY, Pimashkin A, et al. Astrocytic atrophy following status epilepticus parallels reduced $\mathrm{Ca}^{2+}$ activity and impaired synaptic plasticity in the rat hippocampus. Front Mol Neurosci. 2018;11:215.

28. Scemes E, Velíšek L, Velíšková J. Astrocyte and neuronal pannexin1 contribute distinctly to seizures. ASN Neuro. 2019;11:1759091419833502.

29. Manjarrez-Marmolejo J, Franco-Pérez J. Gap junction blockers: an overview of their effects on induced seizures in animal models. Curr Neuropharmacol. 2016;14:759-71.

30. Biswas J, Gupta S, Verma DK, Gupta P, Singh A, Tiwari S, et al. Involvement of glucose related energy crisis and endoplasmic reticulum stress: insinuation of streptozotocin induced Alzheimer's like pathology. Cell Signal. 2018;42:211-26.

31. Sharma P, Srivastava P, Seth A, Tripathi PN, Banerjee AG, Shrivast va SK. Comprehensive review of mechanisms of pathogenesis involved in Alzheimer's disease and potential therapeutic strategies. Prog Neurobiol. 2019;174:53-89.

32. Wang M, Zhou J, He F, Cai C, Wang H, Wang Y, et al. Alteration of gut microbiota-associated epitopes in children with autism spectrum disorders. Brain Behav Immun. 2019;75:192-9.

33. Giaume C, Sáez JC, Song W, Leybaert L, Naus CC. Connexins and pannexins in Alzheimer's disease. Neurosci Lett. 2019;695:100-5.

34. Lu C, Meng Z, He Y, Xiao D, Cai H, Xu Y, et al. Involvement of gap junctions in astrocyte impairment induced by manganese exposure. Brain Res Bull. 2018;140:107-13.

35. Kasap M, Bonnett K, Aamodt EJ, Dwyer DS. Akinesia and freezing caused by $\mathrm{Na}^{+}$leak-current channel (NALCN) deficiency corrected by pharmacological inhibition of $\mathrm{K}^{+}$channels and gap junctions. J Comp Neurol. 2017;525:1109-21. 


\section{A. Sánchez, et al.: Synapses in neuropathological conditions}

36. Phookan S, Sutton AC, Walling I, Smith A, O'Connor KA, Campbell JC et al. Gap junction blockers attenuate beta oscillations and improve forelimb function in hemiparkinsonian rats. Exp Neurol. 2015;265:160-70.

37. Maatouk L, Yi C, Carrillo-de Sauvage MA, Compagnion AC, Hunot S, Ezan $\mathrm{P}$, et al. Glucocorticoid receptor in astrocytes regulates midbrain dopamine neurodegeneration through connexin hemichannel activity. Cell Death Differ. 2019;26:580-96.

38. Fujita A, Yamaguchi $\mathrm{H}$, Yamasaki R, Cui $\mathrm{Y}$, Matsuoka $\mathrm{Y}$, Yamada KI, et al. Connexin 30 deficiency attenuates A2 astrocyte responses and induces severe neurodegeneration in a 1-methyl-4-phenyl-1,2,3,6-tetrahydropyridine hydrochloride Parkinson's disease animal model. J Neuroinflammation. 2018;15:227.

39. Zhang YW, Kaneda M, Morita I. The gap junction-independent tumor-suppressing effect of connexin 43. J Biol Chem. 2003;278:44852-6.

40. Gielen PR, Aftab Q, Ma N, Chen VC, Hong X, Lozinsky S, et al. Connexin43 confers temozolomide resistance in human glioma cells by modulating the mitochondrial apoptosis pathway. Neuropharmacology. 2013;75:539-48.

41. Lai SW, Huang BR, Liu YS, Lin HY, Chen CC, Tsai CF, et al. Differential characterization of temozolomide-resistant human glioma cells. Int $\mathrm{J} \mathrm{Mol}$ Sci. 2018:19:e127.

42. Mettang M, Meyer-Pannwitt V, Karpel-Massler G, Zhou S, Carragher NO Föhr KJ, et al. Blocking distinct interactions between glioblastoma cells and their tissue microenvironment: a novel multi-targeted therapeutic approach. Sci Rep. 2018:8:5527.

43. Pilarczyk G, Papenfuß F, Bestvater F, Hausmann M. Spatial arrangements of connexin43 in cancer related cells and re-arrangements under treatment conditions: investigations on the nano-scale by super-resolution localization light microscopy. Cancers (Basel). 2019;11:e301.

44. Jayalakshmi J, Vanisree AJ, Ravisankar S, Rama K. Site specific hypermethylation of CpGs in Connexin genes 30, 26 and 43 in different grades of glioma and attenuated levels of their mRNAs. Int $\mathrm{J}$ Neurosci. 2019;129:273-82

45. Zhang W, Couldwell WT, Simard MF, Song H, Lin JH, Nedergaard M. Direct gap junction communication between malignant glioma cells and astrocytes. Cancer Res. 1999;59:1994-2003.

46. Chen D, Liu Y, Yang H, Chen D, Zhang X, Fermandes JC, et al. Connexin 43 promotes ossification of the posterior longitudinal ligament through activation of the ERK $1 / 2$ and p38 MAPK pathways. Cell Tissue Res. 2016;363:765-73

47. Ozog MA, Siushansian R, Naus CC. Blocked gap junctional coupling increases glutamate-induced neurotoxicity in neuron-astrocyte co-cultures. J Neuropathol Exp Neurol. 2002;61:132-41.

48. Wang J, Yang ZY, Guo YF, Kuang JY, Bian XW, Yu SC. Targeting different domains of gap junction protein to control malignant glioma. Neuro Oncol. 2018;20:885-96.

49. Machado C, Rodríguez R, Estévez M, Leisman G, Chinchilla M, Portela L, et al. Trastorno del espectro autista: un reto para las neurociencias. Rev Mex Neuroci. 2017;18:30-45.

50. Irwin DJ, Grossman M, Weintraub D, Hurtig HI, Duda JE, Xie SX, et al. Neuropathological and genetic correlates of survival and dementia onset in synucleinopathies: a retrospective analysis. Lancet Neurol. 2017;16:55-65.

51. Fenouil T, Fourier A, Quadrio I, Streichenberger N, Bernardini S, Zima T, et al. The standardization of cerebrospinal fluid markers and neuropathological diagnoses brings to light the frequent complexity of concomitant pathology in Alzheimer's disease: the next challenge for biochemical markers? Clin Biochem. 2019;72:15-23.
52. De Reuck JL. Post-mortem magnetic resonance imaging as an additional tool of the neuropathological examination of neurodegenerative and cerebrovascular diseases. Eur Neurol Rev. 2016;11:22-5.

53. Wall DP, Kosmicki J, Deluca TF, Harstad E, Fusaro VA. Use of machine learning to shorten observation-based screening and diagnosis of autism. Transl Psychiatry. 2012;2:e100.

54. Sato JR, Hoexter MQ, Oliveira PP Jr., Brammer MJ, MRC AIMS Consortium, Murphy $D$, et al. Inter-regional cortical thickness correlations are associated with autistic symptoms: a machine-learning approach. J Psychiatr Res. 2013;47:453-9.

55. Heinsfeld AS, Franco AR, Craddock RC, Buchweitz A, Meneguzzi F. Identification of autism spectrum disorder using deep learning and the ABIDE dataset. Neuroimage Clin. 2018;17:16-23

56. Wang J, Ma M, Locovei S, Keane RW, Dahl G. Modulation of membrane channel currents by gap junction protein mimetic peptides: size matters. Am J Physiol Cell Physiol. 2007;293:C1112-9.

57. Glass BJ, Hu RG, Phillips AR, Becker DL. The action of mimetic peptides on connexins protects fibroblasts from the negative effects of ischemia reperfusion. Biol Open. 2015;4:1473-80.

58. Shiels A, Mackay D, lonides A, Berry V, Moore A, Bhattacharya S. A missense mutation in the human connexin50 gene (GJA8) underlies autosomal dominant "zonular pulverulent" cataract, on chromosome 1q. Am J Hum Genet. 1998;62:526-32.

59. Muller KJ, Scott SA. Transmission at a 'direct' electrical connexion mediated by an interneurone in the leech. J Physiol. 1981;311:565-83.

60. Lo YK, Tang KY, Chang WN, Lu CH, Cheng JS, Lee KC, et al. Effect of oleamide on $\mathrm{Ca}(2+)$ signaling in human bladder cancer cells. Biochem Pharmacol. 2001;62:1363-9.

61. Söhl G, Nielsen PA, Eiberger J, Willecke K. Expression profiles of the novel human connexin genes hCx30.2, hCx40.1, and hCx62 differ from their putative mouse orthologues. Cell Commun Adhes. 2003;10:27-36.

62. Altevogt BM, Kleopa KA, Postma FR, Scherer SS, Paul DL. Connexin29 is uniquely distributed within myelinating glial cells of the central and peripheral nervous systems. J Neurosci. 2002;22:6458-70.

63. Fagerberg L, Hallström BM, Oksvold P, Kampf C, Djureinovic D, Odeberg J, et al. Analysis of the human tissue-specific expression by genome-wide integration of transcriptomics and antibody-based proteomics. Mol Cell Proteomics. 2014;13:397-406.

64. Wallenstein MC, Mauss EA. Effect of prostaglandin synthetase inhibitors on experimentally induced convulsions in rats. Pharmacology. 1984;29:85-93.

65. Abrams C, Rash J. Connexins in the nervous system. In: Connexins: a Guide. Part I: fundamentals of Connexin Biology. Totowa, New Jersey: Humana Press; 2009. p. 43-59.

66. Oyamada M, Oyamada Y, Takamatsu T. Regulation of connexin expression. Biochim Biophys Acta. 2005;1719:6-23.

67. Nielsen PA, Beahm DL, Giepmans BN, Baruch A, Hall JE Kumar NM. Molecular cloning, functional expression, and tissue distribution of a novel human gap junction-forming protein, connexin-31.9. Interaction with zona occludens protein-1. J Biol Chem. 2002;277:38272-83.

68. Wingard JC, Zhao HB. Cellular and deafness mechanisms underlying connexin mutation-induced hearing loss a common hereditary deafness. Front Cell Neurosci. 2015;9:202.

69. Beyer E, Berthoud V. The family of connexin genes. In: Connexins: A Guide. Part I: fundamentals of Connexin Biology. Totowa, New Jersey: Humana Press; 2009. p. 3-27.

70. Söhl G, Willecke K. Gap junctions and the connexin protein family. Cardiovasc Res. 2004:62:228-32. 